THE ROLE OF THE IME IN RECENT

2008 SOVEREIGNDEBT RESTRUCTURINGS: IMPLICATIONS FOR THE POLICY OF LENDING INTO ARREARS

Javier diaz-cassou, Aitor Erce-Dominguez and Juan v vazquez zamora.

Documentos ocasionales N. 0805

\title{
BANCODE ESPANA
}

\author{
Eurosistema
}


THE ROLE OF THE IMF IN RECENT SOVEREIGN DEBT RESTRUCTURINGS:

IMPLICATIONS FOR THE POLICY OF LENDING INTO ARREARS 
THE ROLE OF THE IMF IN RECENT SOVEREIGN DEBT

RESTRUCTURINGS: IMPLICATIONS FOR THE POLICY

OF LENDING INTO ARREARS (")

Javier Díaz-Cassou, Aitor Erce-Domínguez

and Juan J. Vázquez-Zamora(*)

BANCO DE ESPAÑA

(*) We are grateful to Enrique Alberola, Paul Bedford, María Jesús Fernández, Santiago Fernández de Lis, Gregor Irwin, Olivier Jeanne, Pilar L'Hotellerie, Mauro Mecagni, Jeromin Zettelmeyer and seminar participants at the International Monetary Fund and Banco de España for helpful comments and suggestions on an earlier draft. Any remaining errors are sole responsibility of the authors.

$\left.{ }^{\star \star}\right)$ General Directorate of International Affairs. Aitor Erce-Domínguez: aerce@bde.es. 
The Occasional Paper Series seeks to disseminate work conducted at the Banco de España, in the performance of its functions, that may be of general interest.

The opinions and analyses in the Occasional Paper Series are the responsibility of the authors and, therefore, do not necessarily coincide with those of the Banco de España or the Eurosystem.

The Banco de España disseminates its main reports and most of its publications via the INTERNET at the following website: http://www.bde.es.

Reproduction for educational and non-commercial purposes is permitted provided that the source is acknowledged.

@ BANCO DE ESPAÑA, Madrid, 2008

ISSN: 1696-2222 (print)

ISSN: 1696-2230 (on line)

Depósito legal: M.39513-2008

Unidad de Publicaciones, Banco de España 


\begin{abstract}
This paper analyzes the role played by the IMF in eight recent sovereign debt restructurings from a comparative perspective: Argentina (2001-2005), the Dominican Republic (2004-2005), Ecuador (1999-2000), Pakistan (1998-2001), the Russian Federation (1998-2001), Serbia (2000-2004), Ukraine (1998-2000) and Uruguay (2004). Our objective is to identify the various dimensions of the IMF's potential involvement during those processes, and to extract some relevant policy implications to reform the Policy of Lending Into Arrears. We find that the IMF can potentially exert a substantial influence on sovereign debt restructurings by influencing countries' decision to restructure when the debt burden is deemed unsustainable, by providing official finance to substitute for a loss of access to international financial markets, by setting a medium-term domestic adjustment path through conditionality, by providing 'independent' information at a time of heightened uncertainty, and by providing incentives both to creditors and debtors. However, a lack of consistency has tended to characterize the role of the IMF in recent sovereign debt restructurings. In part, this reflects the flexibility with which the IMF has adapted its intervention to country-specific factors. However, we argue that this lack of consistency has tended to exacerbate the uncertainty and information asymmetries that are often associated with sovereign debt restructurings, and that a more systematic approach is needed.
\end{abstract}

JEL codes: E65, F34, H63.

Keywords: IMF, Sovereign Debt, Restructurings, Default, Solvency. 


\section{Introduction}

The issue of sovereign debt restructurings has long figured prominently in the international policy agenda. The beginning of the present decade witnessed an intense debate on whether the international community should adopt a statutory approach centred on the establishment of an official debt restructuring mechanism to address sovereign insolvencies. Ultimately, this proposal was dropped in favour of a less ambitious contractual approach based on the inclusion of collective action clauses and other innovations in international bond issuances. Apart from committing the Institution to promote collective action clauses, this approach left the role of the IMF in coping with sovereign debt restructurings essentially unchanged.

The IMF's toolkit does not include any instrument specifically designed to deal with sovereign debt restructurings. This has provided the IMF with some flexibility to react to specific circumstances on a case by case basis, which has come at the cost of somewhat exacerbating the uncertainty that surrounds the official response to such disruptive episodes in international financial markets. In most cases, the IMF's involvement in debt restructurings has been articulated around a financial program approved either prior to the sovereign's restructuring plan, or as a result of it. Formally, there is no distinction between such programs and "traditional" IMF-supported programs. Only if a country falls into arrears with its external private creditors, as it is often the case during sovereign debt restructurings, does the policy of Lending Into Arrears (LIA) come into effect. This is why the LIA policy is often associated with the role of the IMF in sovereign debt restructurings. However, it is important to note that there is scope both for debt restructurings backed by an IMF program without activating the LIA policy (in the case of "pre-emptive" restructurings in which the sovereign remains current on its external debt payments) and for programs under the LIA policy in which only minor components of sovereign debt are re-negotiated in order to settle pending arrears.

The LIA policy has been included as one of the specific items for revision under the IMF's ongoing medium-term strategic review. One of the reasons why the LIA policy has come under closer scrutiny in recent years is the broad-based discontent with the role played by the Fund during the Argentine debt restructuring (2001-2005). Indeed, this episode raised awareness about a number of shortcomings and ambiguities of the LIA policy, among which the following stand out in particular: (i) the Fund's financial exposure to the country that launches a restructuring tends to generate a conflict of interest for the Institution, and hence reduces its credibility as an impartial/independent player in the crisis resolution process; (ii) the good faith criterion, which conditions the Fund's financial support under the LIA policy, is fundamentally devoid of economic content and judgemental in nature, which leaves scope for arbitrariness in its interpretation; (iii) some have argued that, in order not to interfere with the negotiations between the sovereign debtor and its private creditors, the IMF should restrain from providing the "resource envelope" of the restructuring through its program's macroeconomic framework. Others, instead, argue that this is a key feature of the public good provided by the IMF during a restructuring process; (iv) intimately linked to the above is the ambiguity stemming from the Fund's role as a provider of information and the question of whether the Institution should systematically provide the parties involved in the restructuring with a debt sustainability analysis. 
This paper is aimed at providing food for thought for the upcoming discussion on the review of the LIA policy. It departs from Díaz-Cassou, Erce and Vázquez (2008), a companion paper which comprehensively analyzes 9 sovereign debt restructurings: Argentina, Belize, the Dominican Republic, Ecuador, Pakistan, Russia, Serbia, Ukraine and Uruguay. Here we try to identify the various dimensions of the Fund's involvement in those processes. We focus on the eight cases in which an IMF-supported program was in place in the period surrounding the restructuring and, therefore, we drop the case of Belize from our analysis. Not in all of the cases covered in this paper was the LIA policy formally applied. However, we have extended our analysis beyond proper LIA cases for considering that, whenever a program was in place during the restructuring, the IMF was facing comparable policy challenges. Our idea, therefore, is that non-LIA programs in place during a restructuring can be informative and provide meaningful insights for the design of the LIA policy itself.

The reminder of this paper is organized as follows. Section 2 presents the main features of the IMF's Policy of Lending Into Arrears. In section 3 we present a comparative analysis of the case studies covered in Díaz-Cassou et al. (2008). We concentrate especially on the comparison between pre-emptive and post-default cases, on the degree of comprehensiveness of the various restructurings, and on the discriminatory treatment given to the different categories of domestic and external creditors. Section 4 concentrates more specifically on the role played by the IMF in the debt restructurings. Finally, section 5 concludes and presents some policy implications. 


\section{The Policy of Lending Into Arrears}

Up until 1989 the IMF stuck to a policy of non-toleration of arrears to private creditors, meaning that all financial programs required the elimination of arrears and the non-accumulation of new arrears during the program period. This policy was seen as instrumental to provide both members states and private creditors with the incentives to seek a timely agreement in order to clear arrears and, potentially, to restructure debt. The protraction of the 1980's debt crisis, however, gradually undermined the rationale behind the non-toleration of arrears. Indeed, mainly as a result of the development of a secondary market for banks' claims and of the strengthening of commercial banks' balance sheets, private creditors showed increasing reluctance to engage in constructive negotiations with their sovereign debtors. In this context, the non-toleration of arrears began to be seen as a de facto veto power assigned to commercial banks over the Fund's lending decisions.

The policy of lending into arrears, therefore, was introduced in 1989 as an explicit move to reduce private creditors' leverage over the Fund's decision to provide financial support to crisis countries as well as the ensuing use of that leverage in their direct negotiations with sovereign debtors. The new policy basically legalised the Fund's lending to countries in arrears to commercial banks, subject to the existence of a discernible negotiation process ongoing between the sovereign and its private creditors. It also allowed for a further accumulation of arrears during the program period. This paved the way for a more active IMF involvement in the resolution of the debt crisis, and has remained ever since a pillar of the Fund's role in sovereign debt restructurings.

There have been various modifications of the LIA policy since its inception. In 1998, the policy was broadened to encompass bonded debt reflecting the changing composition of international capital flows and, more precisely, the securitization of sovereign debt. One year later, the policy was modified again to soften the requirements that negotiations be in place in order for a Fund supported program to be approved. Under the new policy, formal negotiations are not required to have begun as long as the member state is deemed to be making a good faith effort to reach a collaborative agreement with its creditors. This change was basically aimed at reflecting that, given the heterogeneity and number of bondholders potentially involved, initiating negotiations for the restructuring of bonded debt is likely to be much more difficult than for syndicated loans. A last modification was introduced in 2002 with the introduction of various principles aimed at providing some guidance for the interpretation of the good faith criterion.

Having reviewed its origins and subsequent modifications, the specific features that characterize the LIA policy remain to be identified. As we have seen, in essence the LIA policy constitutes a legal device to allow the Fund's lending in a set of circumstances in which financial programs were ruled out in the past. There are basically two procedural elements that differentiate a LIA program from a 'traditional' program:

o The inclusion of the good faith criterion as an additional condition for the Fund's disbursements. As mentioned above, this criterion was introduced without a clear definition. This called for a subsequent issuance of some principles to assess whether a member is undertaking efforts to reach a collaborative agreement with 
its private creditors: (i) the member should engage in an early dialogue with creditors, (ii) the member should share relevant information on a timely basis ${ }^{1}$, (iii) the member should provide creditors with an early opportunity to give input on the design of restructuring strategies and the design of individual instruments. Notwithstanding this clarification, the good faith criterion is still perceived as ambiguous and its assessment remains fundamentally judgemental.

o While arrears remain outstanding, financing assurances reviews shall be conducted prior to the disbursement made available after the approval of the arrangement. Such reviews are aimed at determining whether adequate safeguards are in place for the further use of the Fund's resources, and to assess whether the member's adjustment efforts are undermined by developments in debtor-creditors relations.

Beyond these procedural requirements, the LIA policy does not really specify what the role of the IMF should be during a sovereign debt restructuring. It has often been argued that the provision of official financial support may mitigate the economic dislocation caused by the restructuring, thereby contributing to preserve the economic value of creditors' claims and facilitating the normalization of the member's external financial position. In this sense, some have established a parallelism between LIA programs and debtor-in-possession financing in private bankruptcies. There are, however, a number of channels through which the IMF can potentially influence the outcome of a restructuring that go well beyond the mere provision of financial support. First of all, just as any IMF-supported program, LIA programs are constructed upon a macroeconomic framework which includes conditionality over domestic adjustment. If domestic adjustment is interpreted as the counterpart of the "haircut" imposed on creditors as a result of the debt restructuring, the program's macroeconomic framework unavoidably influences the negotiation process. In addition, the IMF can play an important role as a provider of information. This can be particularly important during a restructuring given the heightened uncertainty that tends to surround such episodes. Finally, the IMF can play an active role in a restructuring, for instance if it influences the sovereign's decision to restructure in the first place, if it takes part in meetings with private creditors or if it issues comfort letters to support participation in the exchange.

Not specifying ex ante these dimensions of the Fund's involvement in debt restructurings has provided the Institution with flexibility to adapt to the specific circumstances of each case. The Argentine case, however, tends to put this scheme into question. This paper's departing hypothesis is that the ongoing strategic review may constitute a window of opportunity to go beyond the current procedural approach of the LIA policy, providing it with a clearer economic content to effectively guide the IMF in the various dimensions of its potential role during debt restructurings.

1. This includes an explanation of the economic problems and financial circumstances justifying the debt restructuring, a briefing on the broad outlines of a viable economic program to address the underlying problems and its implications on the broad financial parameters shaping the envelope of resources available for restructured claims, and the provision of a comprehensive picture of the proposed treatment of all claims, including those of official bilateral creditors, and the elaboration of the basis on which the debt restructuring would restore medium-term sustainability, bearing in mind that not all categories of claims may need to be restructured. 
We cover 8 sovereign debt restructurings: Argentina, Dominican Republic, Ecuador, Pakistan, Russia, Serbia, Ukraine and Uruguay. Boxes 1 and 2 briefly put these debt restructurings in context. The IMF was involved in all of these cases through a financial program approved either prior, during and/or after the restructuring. As mentioned above, some of these countries broadly remained current in the service of their external private debt, implying that the LIA policy did not always come into effect. In addition, we have excluded from our analysis cases in which the LIA policy was (or ought to have been) applied as a result of minor external arrears which did not give rise to a broad-based restructuring of sovereign debt. In our view, although relevant for the design of the LIA policy, these cases raise issues clearly differentiated from the sovereign debt restructurings scenarios analyzed here, which we have left for further consideration. Our analysis revolves around four key factors which we consider relevant for a re-framing of the LIA policy. Firstly, we carry out a comparison between preemptive restructurings and post-default restructurings. In the second place, we try to distinguish cases in which the restructuring was comprehensive from those in which the authorities adopted a selective approach. Thirdly, we address the issue of domestic creditors and of whether these were treated differently from external creditors at the various stages of the crises. Finally, we focus on the role played by the IMF in the 8 restructurings analyzed.

\subsection{Pre-emptive vs. post-default restructurings}

A basic differentiation between the restructurings analyzed here is whether these were pre-emptive in nature, or were instead carried out following a sovereign default. In principle, pre-emptive restructurings could be assumed to have been aimed at addressing liquidity problems, while post-default restructurings tend to be associated with situations of insolvency, which is why the debt to GDP ratio at the time of the restructurings tends to be higher in the post-default cases. According to this line of reasoning, the LIA policy should be expected to have been applied in the post-default restructurings. However, reflecting the complicated dynamics of debt restructurings, this association is not always straightforward. Both types of restructurings were, in general, preceded by large rises in the level of external debt. Indeed, as shown in table 1, regarding the liquidity-solvency dichotomy, the situation of some of the preventive and post-default restructurings was ambiguous. In the preventive cases, this would be so for Pakistan and Uruguay, where the debt to GDP ratios stood at $84 \%$ and $103 \%$ respectively at the time the restructurings were launched. In the post-default cases, the debt to GDP ratios of Russia and Serbia stood at significantly lower levels: 52\% and $64 \%$ respectively ${ }^{2}$. The liquidity indicators confirm this ambiguity, given that both Pakistan and Uruguay displayed a higher debt service to exports ratio than Russia, while the total debt service to reserves ratio was higher in the Dominican Republic, Pakistan and Uruguay than in all of our post-default cases. In addition, as a result of minor arrears with specific suppliers or commercial banks, the LIA policy was applied to some pre-emptive cases, such as the Dominican Republic. Given that neither the sustainability of the debt stock nor the intensity of liquidity pressures suffice to explain the authorities' choice to remain current on debt payments during the restructurings, other factors must be at play. To a large extent, the decision to default was circumstantial and highly influenced by country specific political or social factors or by the authorities' capacity to deal with the economic dislocation caused by a crisis. This was clearly the case in Serbia where most of the arrears were

2. We have considered Serbia a case of insolvency given the volume of arrears accumulated during the 90's, and the state of economic dislocation after the war. 
accumulated during the conflict years, or in Argentina, where the default was announced following the fall of the elected government, partly in order to signal a change in the course of economic policies and to calm social unrest. In Ecuador, the default was a by-product of institutional weaknesses and especially fiscal rigidities, which constrained the authorities' ability to stabilize the economy and to formulate an effective crisis resolution package. In Russia, the default was part of broader emergency measures passed after the Parliament (Duma) derailed a stabilization package which could have resumed disbursements under the IMF's supported program.

\section{Box 1: Pre-emptive restructurings}

Dominican Republic: primarily as a result of the mishandling of a banking and currency crisis, the Dominican authorities began experiencing important liquidity pressures in 2003. This led the government to request a treatment from the Paris Club, which was signed in April 2004. In order to seek comparability of treatment by private creditors, a plan to restructure bonded and commercial debt was announced later that year. By June 2005, the bonds' exchange had been completed, and an agreement with the London Club was reached in October 2005. This smooth restructuring was facilitated by the cooperative stance of the authorities, the low "haircuts" involved, and the fact that, in spite of the accumulation of relatively minor arrears, the servicing of external debt was never interrupted.

Pakistan: stemming from the fall in exports and net official inflows that resulted from a deteriorating international environment in Asia and from the imposition of international sanctions, Pakistan experienced a severe liquidity crisis in 1998 and 1999. In spite of some arrears accumulated with official lenders, Pakistan remained broadly current on its external obligations. An agreement reached with the Paris Club in January 1999 to reschedule close to US\$3.25 billion paved the way for the resolution of the Pakistani crisis. In order to comply with the comparability of treatment clause, a further agreement was reached with the London Club in July 1999 and Pakistan completed a successful restructuring of its outstanding Eurobonds in November of that same year.

Ukraine: contagion from the Russian crisis, the ensuing depreciation of the currency and a decline in economic activity triggered increasing difficulties to roll-over incoming debt obligations in 1998, forcing the government to carry out a series of debt restructurings. Initially, a selective approach was adopted as the authorities restructured specific debt instruments (domestic and foreign currency bonds, and a Chase-Manhattan loan) between August 1998 and August 1999. Although contributing to alleviate short-term liquidity pressures, these partial restructurings simply postponed the problem and large repayment obligations were concentrated in years 2000 and 2001. As a result, in February 2000 the government launched a comprehensive restructuring, involving external bonds with a face value of close to US\$3.3 billion. Eventually, 99\% of creditors participated in the exchange, accepting an average haircut estimated at 32\%. Completing the debt restructuring, an agreement was reached with the Paris Club in 2001 to treat bilateral debt amounting to about US\$580 million.

Uruguay: after years of economic stagnation compounded by a banking crisis resulting from large deposit withdrawals first by Argentines and then by residents, Uruguay was forced to float its currency in June 2002. This caused a large depreciation of the peso which, together with the fiscal cost of the banking crisis, led to a sharp increase in the debt to GDP ratio pushing the country to the brink of default. With the support of the IMF, on March 2003 the authorities announced their intention to carry out a market-friendly debt restructuring to 
moderate short-term liquidity pressures and improve the medium-term servicing profile of foreign currency denominated sovereign debt. Eventually, although a debt exchange was successfully settled on May 2003, several observers questioned whether the associated debt relief was sufficient to secure the sustainability of Uruguay's debt.

Another factor that may influence the authorities' choice is that remaining current on debt payments tends to facilitate the restructuring. Table 1 shows that pre-emptive restructuring were quicker to complete: 4 quarters on average against 7 quarters in the post-default cases. In addition, it would seem that the countries that restructured pre-emptively managed, on average, to secure a higher creditor participation in the debt exchange than in the post-default scenario: $97 \%$ against $88 \%$.

\section{Box 2: Post-default restructurings}

Argentina: after several quarters of economic stagnation resulting mainly from a combination of external shocks, loose fiscal policy, structural rigidities and a progressive deterioration in the country's perceived creditworthiness, in December 2001 the Argentine government defaulted on its sovereign debt. This set the stage for the largest debt restructuring in recent history, which has been characterized by its complex, protracted and contentious nature. It took close to 21 months for the authorities to present a first restructuring offer, and the debt exchange could not be opened until February 2005, more than three years after the default. Even after the completion of the exchange, holdout creditors' claims remain to be settled, and an agreement with bilateral official creditors has not yet been reached.

Ecuador: a banking collapse, domestic institutional weaknesses, loose macroeconomic policies and a succession of exogenous shocks combined in the late 1990's to trigger a severe financial crisis in Ecuador. As a result, in October 1999 Ecuador became the first country ever to default on its Brady bonds, and a few months later the sucre was dropped in favour of the dollar as the national legal tender. Throughout year 2000, a comprehensive debt restructuring was carried out, including Brady and Eurobonds as well as official bilateral loans through the Paris Club. By May 2001 arrears had been completely cleared, with close to $97 \%$ of eligible bondholders having accepted the substantial losses included in the terms of the restructuring.

Russia: following the rejection of a comprehensive fiscal adjustment by the Duma, in August 1998 Russia shocked the international financial community by devaluating its currency, defaulting on its rouble denominated debt and imposing a 90-days moratorium on private sector repayments on external creditors. Although the government made a first restructuring offer as early as August 25 of that same year, no exchange offer could be launched until March 1999 (the so-called Novation scheme) partly because of the lack of a credible domestic adjustment program to back the government's proposal. Throughout this process, Russia serviced external debt issued after 1992, while accumulating substantial arrears on Soviet-era debt. No agreement to restructure bilateral official debt could be reached until August 1999 given that no on-track IMF program (a pre-condition for a Paris Club treatment) was in place until the month of July of that same year. A third component of the Russian debt restructuring was the London Club agreement signed in August 2000. 
Serbia \& Montenegro: at the turn of the century, the Yugoslav debt to GDP ratio was close to $145 \%$ of GDP. Given that external debt servicing had been interrupted during the military conflicts of the 1990's, more than $80 \%$ of that debt was in arrears to private and public creditors, including multilateral organizations. The overthrow of the Milosevic regime and other important political changes in the second half of year 2000 paved the way for the normalization of Serbia's external relations: international sanctions were lifted, arrears to the World Bank and the IMF were cleared, and the membership of the Federal Republic of Yugoslavia to both institutions was resumed. Following the approval of an IMF-supported program, an agreement was reached with the Paris Club in November 2001, treating close to $37 \%$ of external debt. Negotiations with the London Club and other commercial creditors, however, were much more protracted, and no settlement could be agreed until July 2004 after which most Serbian arrears were cleared. These successive restructurings brought the Serbian debt to GDP ratio down to about $60 \%$.

However, it is worth noting that these results are clearly biased by the Argentine case which, as mentioned above, was especially protracted and contentious. The clearest incentive to restructure pre-emptively, instead, may lie in the objective of recovering access to international financial markets. Indeed, all of the indicators used in table 1 suggest that the countries that remained current on external debt payments managed to tap international financial markets more quickly than defaulters. This is especially clear for the Dominican Republic and Uruguay, and less so for Ukraine and Pakistan which, in any case, had limited access to international financial markets also prior to the restructuring. Among the post-default cases, Russia was the country which recovered access to international financial markets quicker. This may be so because the Russian government defaulted on securities issued domestically while remaining current on post-soviet debt issued abroad.

On the other hand, table 1 shows that "haircuts" measured in NPV terms were much larger in post-default restructurings than in the pre-emptive cases: on average $41.8 \%$ against $19.2 \%$. Furthermore, the share of debt affected by the restructuring both to GDP and to total debt was also higher in the post-default cases, implying that the extent of debt relief was significantly larger for defaulters. This may be so because the act of defaulting tends to alter the bargaining power of private creditors and the sovereign debtor in favour of the latter. Indeed, in pre-emptive cases the liquidity relief is felt only after the debt exchange has been completed but not during the negotiation phase. Instead, in post default cases the completion of the debt exchange has the opposite effect given that it usually coincides with the resumption of debt servicing. Indeed, as illustrated especially by the Argentine case, every month of delay in the settlement of a default can generate substantial savings in foregone interest payments. As a result, defaulters may have a financial incentive to delay the agreement and search for harsher restructuring terms, while non-defaulters' best interest lies in reaching a quick agreement, which tends to come at the expense of a larger debt relief.

The shift in bargaining power from the debtors to the creditor entailed by the act of defaulting is illustrated in Chart 1. The various restructurings analyzed in this paper are ordered according to the authorities' degree of coerciveness for which we use the index developed by Enderlein et al. (2007). As we can see, the most coercive debt restructurings analyzed here do clearly correspond to the post-default ones. In that respect, a comparison between the debt restructurings of Argentina and Uruguay is particularly illustrative: while the former took all its time to launch the debt exchange and impose large losses on bondholders, 
the latter emphasized the market-friendly nature of its restructuring, securing a fast settlement with moderate losses for investors.

It would seem, therefore, that the decision to default or to remain current on debt obligations has a strategic component and may be associated with the existence of a tradeoff between greater debt relief or a quicker access to international financial markets. Ultimately, it is difficult to determine which category of restructurings had a better outcome. If the restoration of debt sustainability is taken as the main parameter to assess the outcomes of the restructurings, our case studies yield ambiguous results. Indeed, the two cases in which debt sustainability was more questioned following the restructuring were Argentina and Uruguay, which constitute to some extent the epitomes of our post-default and pre-emptive cases. The comparison of the evolution of post-restructuring GDP growth in pre-emptive and post-default cases also yields inconclusive results.

Table 1: Key features of pre-emptive VS post-default cases

\begin{tabular}{|c|c|c|c|c|c|c|c|c|c|c|c|c|c|}
\hline \multirow[b]{3}{*}{ Country } & \multicolumn{3}{|c|}{ Nature of the problem. } & \multicolumn{4}{|c|}{ Debt affected by restructuring } & \multicolumn{3}{|c|}{ Debt Exchange } & \multicolumn{3}{|c|}{ Access to int'l capital markets. } \\
\hline & \multirow[b]{2}{*}{ Debt/GDP1 } & \multicolumn{2}{|c|}{ Liquidity } & \multirow[b]{2}{*}{$\begin{array}{c}\text { Liquidity VS } \\
\text { Solvency }\end{array}$} & \multirow[b]{2}{*}{$\begin{array}{c}\begin{array}{c}\text { Total } \\
\text { (\$US } \\
\text { million) }\end{array} \\
\end{array}$} & \multirow[b]{2}{*}{$\begin{array}{l}\% \text { of } \\
\text { GDP }\end{array}$} & \multirow[b]{2}{*}{$\begin{array}{c}\% \text { of total } \\
\text { debt }\end{array}$} & \multirow[b]{2}{*}{$\begin{array}{c}\text { Duration } \\
\text { (quarters) } \\
2,3\end{array}$} & \multirow[b]{2}{*}{$\begin{array}{l}\text { NPV } \\
\text { loss }\end{array}$} & \multirow[b]{2}{*}{$\begin{array}{c}\text { Particip. } \\
\text { (\%) }\end{array}$} & \multirow{2}{*}{$\begin{array}{l}1^{\text {st }} \text { int'l } \\
\text { bond } \\
\text { issuance } \\
\text { ( } 3 \text { month } \\
\text { periods) }\end{array}$} & \multirow{2}{*}{$\begin{array}{c}\text { EMBI } \\
\text { level at } \\
\text { last } \\
\text { issuance }\end{array}$} & \multirow{2}{*}{\begin{tabular}{|c|} 
EMBI \\
level \\
below \\
1000 \\
p.b
\end{tabular}} \\
\hline & & $\begin{array}{c}\text { Debt } \\
\text { service } \\
\text { /Xs } \\
\end{array}$ & $\begin{array}{c}\text { TDS to } \\
\text { reserves }\end{array}$ & & & & & & & & & & \\
\hline \multicolumn{14}{|l|}{$\begin{array}{c}\begin{array}{c}\text { Pre- } \\
\text { emptive }\end{array} \\
\end{array}$} \\
\hline DR & $56 \%$ & 0.08 & 3.53 & Liquidity & 1628 & $10 \%$ & $17.5 \%$ & 5 & 1 & 97 & 8 & 5 & 2.5 \\
\hline Pakistan & $84 \%$ & 0.22 & 1.41 & Ambiguous & 19041 & $31 \%$ & $61 \%^{4}$ & 12 & 30 & 99 & 21 & - & 12 \\
\hline Ukraine & $42 \%$ & 0.07 & 0.57 & Liquidity & 4689 & $9 \%$ & $53 \%^{4}$ & 7 & 32 & 99 & 17 & - & 13 \\
\hline Uruguay & $103 \%$ & 0.40 & 4.20 & Ambiguous & 5300 & $43 \%$ & $42 \%$ & 1 & 14 & 93 & 3 & 7 & 1 \\
\hline Average & $71.25 \%$ & 0.19 & 2.42 & & 7664.5 & $23.2 \%$ & $43.3 \%$ & 4 & 19.2 & 96.8 & 12.25 & 6 & 7.1 \\
\hline \multicolumn{14}{|l|}{$\begin{array}{l}\text { Post- } \\
\text { default }\end{array}$} \\
\hline Argentina & $130 \%$ & 0.30 & 0.65 & Solvency & 82000 & $30 \%$ & $56 \%$ & 13 & 73 & 76 & 20 & 14 & 14 \\
\hline Ecuador & $101 \%$ & 0.35 & 1.19 & Solvency & 7475 & $45 \%$ & $44.5 \%$ & 4 & 26 & 97 & 24 & - & 16.5 \\
\hline Russia & $52 \%$ & 0.07 & 0.39 & Ambiguous & 40113 & $24 \%$ & $39^{\star 4}$ & 4 & 48 & 92 & 13 & 15 & 11 \\
\hline Serbia & $64 \%$ & n.a. & n.a. & Solvency & 7124 & n.a. & n.a. & - & 62 & - & Not yet & - & - \\
\hline Average & $86.75 \%$ & 0.24 & 0.74 & & 34178 & $33 \%$ & $47 \%$ & 7 & 41.8 & 88.3 & 19 & 14.5 & 10.3 \\
\hline
\end{tabular}

Source: Own calculations based on GDF, WDI, IADB, and IMF.

${ }_{1}^{1}$ Closest available data to the launching of the exchange

2 From the authorities' announcement of the re-structuring plan to the official closure of the exchange.

${ }^{3}$ From the default to the official closure of the exchange.

${ }^{4}$ Calculations only over total external debt. 


\section{Chart 1: Degree of coerciveness of pre-emptive vs. post-default restructurings}

\begin{tabular}{|c|c|c|}
\hline Degree of coerciveness & $\begin{array}{l}\text { Argentina, } 2005 \text { Global Bond Restructuring } \\
\text { Russia, 1998-1999 Domestic Restructuring } \\
\text { Ecuador, 2000 Bond Restructuring } \\
\text { Argentina, } 2001 \text { Domestic Restructuring } \\
\text { Russia, 1998-1999 Foreign Restructuring } \\
\text { Pakistan, 1999 Bonded Debt Restructuring } \\
\text { Dominican Republic, } 2005 \text { Bonded Debt Restructuring } \\
\text { Ukraine, 2000, Comprehensive Restructuring } \\
\text { Ukraine 1999, ING \& Merryl Lynch debt workouts } \\
\text { Argentina, } 2001 \text { Mega-swap } \\
\text { Uruguay, } 2003 \text { Bond Exchange }\end{array}$ & $\begin{array}{l}\text { (Post-default) } \\
\text { (Post-default) } \\
\text { (Post-default) } \\
\text { (Pre-emptive) } \\
\text { (Post-default) } \\
\text { (Pre-emptive) } \\
\text { (Pre-emptive) } \\
\text { (Pre-emptive) } \\
\text { (Pre-emptive) } \\
\text { (Pre-emptive) } \\
\text { (Pre-emptive) }\end{array}$ \\
\hline
\end{tabular}

Source: Henrik Enderlein, L Muller \& C. Trebesh (2007)

\subsection{Partial vs. comprehensive debt restructurings}

Another important distinction is whether the sovereign adopted a partial or a comprehensive debt restructuring strategy. Under the first approach, the sovereign focalized the restructuring in more or less specific debt instruments. Presumably, this tended to be the case when liquidity pressures were mostly generated by these specific debt instruments, or when the sovereign tried to ring-fence certain categories of debt in order to limit the disruption caused by the restructuring. The sovereign opted for a more comprehensive approach if the main categories of debt were involved in the restructuring (with the exception of multilateral obligations given the preferred creditor status of the IMF and other international financial institutions). Presumably, this tended to occur when liquidity pressures were so widespread that the restoration of debt sustainability required the involvement of most creditors in the restructuring, or when the sovereign tried to preserve some level of 'fairness', inter-creditor equity and thereby a market friendly approach.

Most of the case studies covered here have featured some degree of selectiveness at some point of the debt restructuring process. During the early stages of the debt crisis, this selective approach was particularly discernible in Argentina and Russia. In both cases, the authorities tried to alleviate short-term liquidity pressures through voluntary debt exchanges: the so-called June 2001 mega-swap in Argentina, and the July 1998 exchange of ruble denominated debt for Eurobonds in Russia. Eventually, both attempts not only failed to prevent the crisis and avoid a broader restructuring of debt or a default, but were counter-productive. Indeed, although the Argentine US\$29.5 billion mega-swap involved a debt relief of about US $\$ 15$ billion for the period 2001-2005, it increased debt repayments after 2006 by as much as US $\$ 65$ billion, further pushing the Argentine economy into insolvency. In turn, the low participation in the Russian debt exchange (US $\$ 4.4$ billion of a total eligible debt of US $\$ 41$ billion) is considered to have acted as a wake up call, fuelling investors' concerns and further feeding upward pressures on spreads. Both the cases of Argentina and Russia, therefore, illustrate the risk posed by financial engineering operations designed to bridge short-term liquidity pressures in times of heightened vulnerability.

After these failed attempts to bridge liquidity pressures, the authorities of both countries were forced to broaden the scope of their restructuring. Russia, however, managed to stick to a selective approach and limited the default to domestically issued bonds while remaining current on most internationally issued debt, with the exception of external obligations inherited from the Soviet Union. In Argentina, the authorities tried to discriminate between various categories of creditors by phasing the restructuring: in phase I debt held by residents was exchanged for loans, and a phase II was contemplated to restructure debt held by non residents. Eventually, however, Argentina defaulted soon after completing phase I, and the restructuring was disorderly broadened to encompass most of its sovereign debt, 
reducing the government's room for manoeuvre to discriminate between categories of creditors.

At the outset of their respective debt crises, Ecuador and Ukraine also tried to limit the scope of their restructurings to specific categories of debt. Originally, Ecuador suspended coupon payments only on its PDI and Discount Brady bonds and tried to persuade investors to limit the restructuring to that type of debt. Eventually, however, Ecuador also defaulted on its Eurobonds and was forced to carry out a comprehensive restructuring which involved some categories of domestic and bilateral official debt. In Ukraine, as mentioned above, the authorities carried out a wave of selective restructurings during 1998 and 1999 involving specific domestic and foreign bonds as well as loans. This, however, simply postponed the problem and Ukraine was forced to launch a comprehensive restructuring of its international bonds as early as February 2000.

A very specific scenario arises when the authorities' most immediate concern is to restructure bilateral official debt. In such circumstances, an agreement with the Paris Club tends to be sought in the first place. One of the conditions attached to Paris Club arrangements is the so-called comparability of treatment clause, which commits the sovereign to secure debt relief from private creditors on a similar scale as that granted previously by official creditors. As a result, the scope for a selective approach is reduced, and the authorities are forced to involve private creditors even when liquidity pressures are likely to have been sufficiently addressed with the Paris Club treatment. The Dominican Republic, Pakistan and Serbia can be said to be in this scenario. While in the Dominican Republic the amount of bonded debt eventually involved in the restructuring significantly exceeded the volume of the Paris Club treatment, in Pakistan private external debt was marginal, and its restructuring had a minor impact in terms of the restoration of debt sustainability (see Chart 2). In Serbia, the Paris Club treatment was part of a broader effort to normalize the country's external relations after the end of the war, which required a substantial debt relief in order to clear existing arrears. In this sense, the Paris Club agreement paved the way for negotiations with private creditors, and for the London Club agreement which was eventually reached in 2004.

Not all of the restructurings studied here have involved the Paris Club. In Uruguay, no treatment was agreed presumably because the authorities opted not to call in the Paris Club given that bilateral official debt was such a minor component of sovereign debt at the time of the restructuring. In Argentina, no comprehensive agreement with bilateral creditors could be reached. After the early cancellation of the IMF-supported program, this has been partly due to the fact that one of the key pre-conditions for a Paris Club treatment was no longer met. However, prior to that, other obstacles must have prevailed given that, although IMF programs were in place from January 2003 to August 2004, the opportunity to reach an agreement with the Paris Club which was not seized. Conversely, Ecuador and Ukraine signed a Paris Club treatment after having completed their respective private debt restructurings. Indeed, Ecuador signed an agreement with the Paris Club in September 2000, a few weeks after the official closure of the private debt exchange. In Ukraine, the Paris Club agreement was signed in July 2001, months after the completion of the private debt restructuring. In any case, our case studies shows that the comparability of treatment principle is not necessarily reciprocal: only if the Paris Club acts as the first mover in the restructuring is the sovereign committed to seek comparable treatment from private and official creditors. As a result, the timing of the Paris Club involvement may be strategic: sovereigns may have an incentive to postpone treatments in order to retain their ability to discriminate among investors and types of debt. 
Chart 2: Debt restructurings' burden sharing ${ }^{34}$
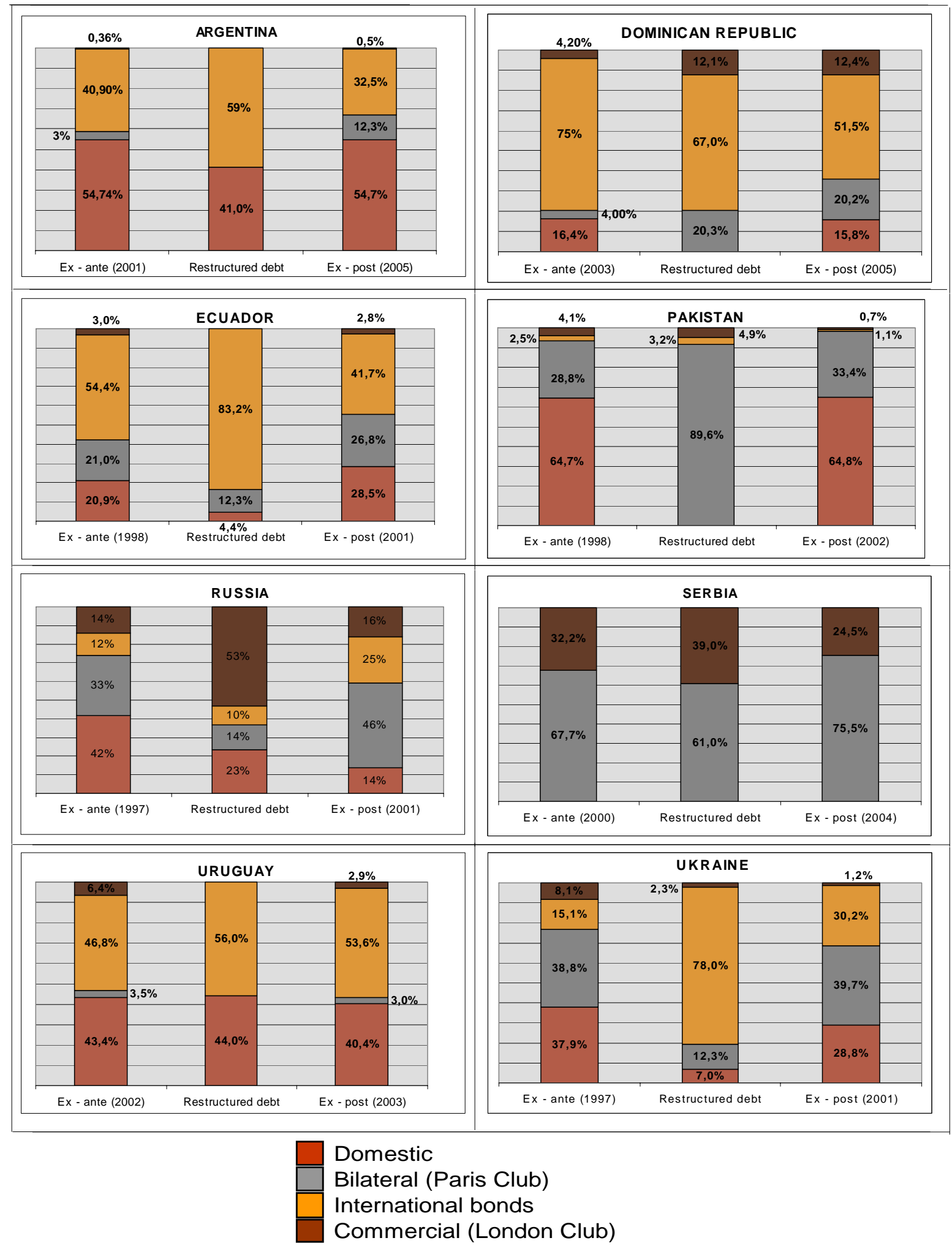

3. Multilateral debt is excluded.

4. This graph does not reflect NPV losses assumed by each category of creditors. As a result, it does not fully capture the burden sharing of the restructurings. However, it gives an idea about the comprehensiveness of the respective restructurings. 
Not all of the restructurings studied here have involved the Paris Club. In Uruguay, no treatment was agreed presumably because the authorities opted not to call in the Paris Club given that bilateral official debt was such a minor component of sovereign debt at the time of the restructuring. In Argentina, no comprehensive agreement with bilateral creditors could be reached. After the early cancellation of the IMF-supported program, this has been partly due to the fact that one of the key pre-conditions for a Paris Club treatment was no longer met. However, prior to that, other obstacles must have prevailed given that, although IMF programs were in place from January 2003 to August 2004, the opportunity to reach an agreement with the Paris Club which was not seized. Conversely, Ecuador and Ukraine signed a Paris Club treatment after having completed their respective private debt restructurings. Indeed, Ecuador signed an agreement with the Paris Club in September 2000, a few weeks after the official closure of the private debt exchange. In Ukraine, the Paris Club agreement was signed in July 2001, months after the completion of the private debt restructuring. In any case, our case studies shows that the comparability of treatment principle is not necessarily reciprocal: only if the Paris Club acts as the first mover in the restructuring is the sovereign committed to seek comparable treatment from private and official creditors. As a result, the timing of the Paris Club involvement may be strategic: sovereigns may have an incentive to postpone treatments in order to retain their ability to discriminate among investors and types of debt.

Uruguay stands out in particular as being a case in which the authorities went at great length to preserve a market-friendly approach during the restructuring process. To some extent, this was aimed at differentiating the Uruguayan debt restructuring from the disorderly Argentine default. One of the manifestations of this market friendly approach was the absence of discriminatory practices between types of creditors. Indeed, from the outset Uruguay involved most of its non-multilateral sovereign debt and, as shown in Chart 2, creditors shared the burden of the restructuring quite proportionally to the ex ante structure of sovereign debt, which tends to signal a rather comprehensive approach. However, even in that case official bilateral debt and international loans were spared from the restructuring, presumably because both categories of debt were relatively minor components of total debt.

Chart 2 compares the ex ante structure of sovereign debt at the outset of the restructuring with the relative weight of the various types of debt ultimately involved in the restructuring, and the ex post structure of sovereign debt. In principle, those cases in which the relative weights of restructured debt are similar to the ex ante structure of sovereign debt should be associated with a comprehensive approach. Accordingly, the most comprehensive restructurings of our sample seem to have been the Serbian and Uruguayan cases. In spite of the selective approach described above, the Argentine debt restructuring, together with the Dominican one, can be labelled as intermediate cases in terms of their comprehensiveness. In turn, the restructurings in Ecuador, Pakistan, Russia and Ukraine seem to have been rather selective. In the case of Russia this was partly due to the weight of Soviet era debt in the restructuring, and to the fact that the default was limited to domestically issued debt. In Ecuador, Pakistan and Ukraine, the selectiveness in the restructuring arises mainly because, to varying extents, domestic creditors were spared from the restructuring.

\subsection{Domestic vs. external creditors}

Partly as a result of an increase in the share of sovereign debt held by residents in emerging markets, some recent restructurings have featured an extensive involvement of domestic creditors in the crisis resolution strategy. This was the case especially for Argentina, Russia and Uruguay, and less so for Ecuador and Ukraine. In the cases of the Dominican Republic, 
Pakistan, Serbia and Ukraine, domestic debt was either a minor component of sovereign debt, or was mostly spared from the restructuring. In addition, it is worth noting that financial globalization makes it increasingly difficult to distinguish between domestic and external debt given that the opening up of the capital account enables residents to hold debt issued by their sovereign in foreign jurisdictions, and foreign investors to acquire claims issued domestically. In this context, the jurisdiction of issuance seems to be losing relevance as an indicator of creditors' nationality.

In any case, domestic debt instruments and domestic creditors have certain specific features that deserve special attention. First of all, resident creditors are by definition subject to the domestic legal and regulatory framework, implying that the sovereign has more tools at its disposal to encourage or even coerce into their participation in a debt exchange. Furthermore, this "jurisdictional" feature implies that litigation tends to be less disruptive for the sovereign when involving domestic creditors in a debt restructuring. Second, if the sovereign remains current on its external obligations while defaulting or imposing a restructuring on domestic debt, it might retain some degree of access to international financial markets, especially if investors believe in the authorities' commitment and capacity to discriminate between types of debt. Third, the restructuring of debt held by residents has a direct impact on the domestic economy, adding up to the burden already caused by the adjustment process taking place as a result of the crisis. Furthermore, a large portion of the sovereign debt held domestically is often in the hands of banks or other institutional investors such as pension funds (especially in countries that have reformed their pension systems from PAYG to fully funded systems). As a result, the restructuring of domestic debt can have a very negative impact on the solvency of the domestic financial system: on the asset side the "haircut" associated with the restructuring constitutes a direct loss for financial institutions, while on the liability side the restructuring of sovereign debt can trigger a confidence loss and potentially large scale deposit withdrawals. Finally, political economy considerations may also be at play, given that domestic creditors are more likely to influence the sovereign's decision making process than external ones.

\section{Box 3: discrimination between domestic and foreign creditors}

Argentina: during the pre-default phase of the Argentine crisis, as access to international financial markets was gradually lost, the authorities resorted to a variety of increasingly heavy-handed measures to mobilize domestic sources of finance. These included the exertion of moral suasion on domestic investors to absorb sovereign debt (the Patriotic bond), financial engineering operations to relieve short-term liquidity pressures at the expense of increasing the long-term burden of debt (the mega-swap) or the November 2001 exchange of domestic debt for guaranteed loans supposedly collateralized with revenues from the financial transaction tax. As a result, the ratio of debt held by residents to total sovereign debt rose from 33\% to $41 \%$ in 2000 and 2001. The December 2001 default, instead, was originally targeted at foreign creditors, given that by that time most Argentine residents had supposedly exchanged their bonds for guaranteed loans, which were excluded from the default. When the government pesified these loans, however, many residents swapped them back for the original bonds in default. Some did so voluntarily, exerting a right that was included in the November debt exchange, while others (mainly pension funds) were forced to swap back guaranteed loans for not accepting the terms of the pesoization. Ultimately, the authorities granted a special treatment (lower haircut) to domestic pension funds in recognition of their coerced absorption of sovereign debt in late 2001. 
Ecuador: the share of domestic to total sovereign debt at the time of the restructuring was close to $16 \%$. As part of its default, Ecuador suspended servicing domestic obligations maturing between September 1999 and end-2000 involving debt with a face value of approximately US\$346 million (close to 15\% of total domestic debt). During the restructuring process, the government clearly differentiated between domestic and external creditors, offering residents much more lenient terms. Indeed, according to the IMF, the exchange of domestic debt for a new bond was effectively equivalent to a roll-over aimed primarily at alleviating liquidity pressures, and carrying practically no NPV loss.

Russia: as opposed to other cases analyzed here, rather than mobilizing domestic sources of finance to substitute for a loss of access to international financial markets, during the months leading to the August default, the Russian authorities were substituting ruble-denominated bonds for lower-yielding debt issued abroad. This was motivated by the short-term maturity profile of domestically issued bonds, which were absorbing the bulk of the upward pressures on yields. In addition, Russia enjoyed access to international financial markets up until a late stage of the crisis partly because it was perceived as being "too big" or "too nuclear" to fall, thereby creating expectations for an international bailout should the need arise. The restructuring of the Russian bonded debt had a clear domestic bias. Indeed, on August 1998 Russia defaulted solely on domestically issued bonds, $70 \%$ of which was estimated to be in the hands of residents. This is explained first and foremost by the aforementioned fact that the domestic bond market was generating most of the liquidity pressures undergone by the authorities. However, another motivation is likely to have been that of avoiding international litigation, and exploiting a "jurisdictional" advantage in the restructuring negotiations. Foreign creditors involved in the restructuring, however, were forced to deposit proceeds in restricted non-interest ruble accounts, and were faced with 5-years repatriation restrictions. This added substantial losses on the haircut already imposed by the restructuring, thereby moderating the aforementioned domestic bias. Ultimately, the bulk of holdout creditors (paid in full but subject to repatriation restrictions) were non-residents.

Ukraine: In the case of Ukraine most of the restructured debt was held by external creditors. However, some of the domestic T-bills restructured in 1998 were in the hands of both domestic banks and international investors. The terms of the restructuring were milder for domestic investors (around 7\%) than for foreign ones (40\%). During the second restructuring, in order to respect inter-creditor equity, Ukraine was in technical default for a brief period.

These features of domestic debt pose significant trade-offs for the authorities and may have a bearing on the restructuring strategy ultimately chosen. Indeed, the aforementioned factors create incentives for the sovereign to discriminate between resident and non-resident creditors. On the one hand, if the sovereign is experiencing important liquidity pressures, it may opt to exhaust all potential domestic sources of finance in an attempt to remain current on its external obligations or to substitute for the loss of access to international financial markets. In the most extreme cases, this may entail a more or less forced restructuring of domestic sovereign debt. Under this scenario, the cost of that restructuring for the domestic economy is presumably deemed lesser than that of losing access to international financial markets and facing disruptive litigation from external creditors. On the other hand, the sovereign may focus on limiting the direct impact of the restructuring on the domestic economy and/or keeping the financial system afloat. Under this 
scenario, the authorities may opt to discriminate against external creditors, for instance by offering softer restructuring terms to domestic creditors or by excluding certain categories of domestic creditors from the restructuring.

We find instances of both types of discrimination in the case studies covered here. The most relevant experiences are highlighted in Box 3. In Ecuador and Ukraine, the terms of the restructuring were worse for non-residents, presumably in order to mitigate the impact of the restructuring on the domestic economy. In the cases of Argentina and Russia, however, the direction of this discrimination is ambiguous. In Argentina, during the pre-default phase of the crisis, the authorities went at great length to involve domestic creditors and eventually carried out a semi-coercive restructuring of debt held by residents which has often been equated to a domestic default. In this way, the sovereign gambled for resurrection in an attempt to save the convertibility regime and to avoid external default. Once that strategy failed, the authorities focused the restructuring on external debt, although a substantial number of residents were ultimately also involved in the default. In Russia, the government defaulted on domestically issued debt while remaining current on post-Soviet debt issued abroad. This was primarily due to the fact that liquidity pressures stemmed mainly from the domestic market, although the objectives of avoiding international litigation and mitigating the loss of access to international financial markets are also likely to have played a role. The non-residents that were caught in the restructuring of GKOs and OFZs, however, suffered worse terms, given that on top of the restructuring, they faced capital controls restricting the repatriation of cash proceeds.

Although our evidence is limited, some patterns seem to emerge as regards the involvement of domestic creditors in sovereign debt restructurings. The cases of Argentina and Russia suggest that prior to an external default domestic investors are more likely to be coerced into further accumulating sovereign debt or accepting some debt relief in order to provide the sovereign with breathing space to service external debt. However, once the sovereign has defaulted on foreign debt, as occurred in Argentina and Ecuador, non-residents tend to bear the restructuring's burden in order to soften the impact of the crisis on the domestic economy. The state of the financial sector is likely to play a role in this sequencing. Indeed, the Argentine banking sector was perceived to be in a relatively good footing prior to the default, which may have led to an underestimation of the risks associated with further increasing banks' holdings of sovereign debt. Instead, in Ecuador and some of the other cases of our sample such as the Dominican Republic, the banking crises originated the crisis, which probably encouraged the authorities to limit domestic banks' involvement in the restructuring. In Russia, a low level of financial intermediation together with the public ownership of the main banks (and the ensuing implicit sovereign guarantee on deposits) may have reduced the perceived impact of the restructuring on the economy, thereby explaining its domestic bias. 


\section{The role of the IMF}

The IMF was involved in all of our case studies through a financial program. Yet, as shown in Appendixes 1 and 2, the size, conditions and timing of these programs vary from case to case, with important implications for the role ultimately played by the Fund in the respective sovereign debt restructurings. A first relevant distinction between the cases under consideration is whether the LIA policy was effectively applied. As we can see in Appendix 1, arrears with external private creditors co-existed with IMF supported programs in the cases of Argentina, Dominican Republic, Ecuador, Russia, Serbia and Ukraine ${ }^{5}$. However, program-related documents do rarely specify whether the LIA policy was activated in these cases neither at the time of the approval of the program, nor at subsequent reviews. Furthermore, the fulfilment of the procedural requirements of the LIA policy (financing assurances reviews and good faith criterion) does not seem to have been always systematically assessed, at least in the cases of Ecuador, Russia and Ukraine. Even when program-related documents refer to these procedural requirements, the assessment of their fulfilment is brief and unarticulated. As a result, these programs do not differ substantially from 'traditional' ones, which tends to blur the specificities of the LIA policy.

Regarding the starting point of the Fund's program involvement in debt restructurings, two broad groups of countries can be identified:

o Countries with inherited programs: the IMF had been continuously involved in Argentina, Pakistan, Russia and Ukraine for several years prior to the crisis and the launching of the restructuring. In Pakistan and Ukraine, this program involvement was uninterrupted throughout the restructuring in spite of relatively short periods in which the programs went off-track. The Fund's involvement in Argentina and Russia was much more complex. Indeed, both programs went off-track just prior to the default, and remained so during important phases of the restructuring. In the case of Argentina, a new transitory program was approved in January 2003, later to be succeeded by a three years SBA signed in September of that same year. Eventually, however, that program was suspended in August 2004. Various factors contributed to the suspension of the Argentine program such as the limited progress with the program's structural agenda or the authorities' lack of progress with the restructuring. Another factor behind the suspension was the authorities' willingness to avoid the IMF program to interfere with the negotiation process with bondholders going on at that time. In Russia, a new 17-months SBA was signed in July 1999, once the novation scheme had already been completed. Russia made only one purchase under that arrangement, partly as a result of considerable slippages in the program's structural benchmarks. In 2000, after having served as a stepping-stone for the Paris Club treatment, that program was cancelled.

o Countries with new programs: in the Dominican Republic, Ecuador, Serbia and Uruguay no IMF program was in place prior to the eruption of the crisis. This is clearer in Ecuador and Serbia, where the programs were approved only after their defaults had been consummated. Instead, in the Dominican Republic and

5. Instead, Uruguay was a purely pre-emptive case in which the sovereign fully honoured its external obligations during the period under consideration, while in Pakistan some arrears were accumulated with official external creditors, implying that the LIA policy was never triggered. 
Uruguay, the IMF stepped in to respond to unfolding financial crises but prior to the announcement of the debt restructurings. A first SBA was approved for the Dominican Republic in August 2003. Although this program served as the basis for the Paris Club treatment, only the first review could be completed before the program went off-track. Instead, the new 28-months SBA approved in January 2005 was implemented successfully. As for Uruguay, a first precautionary arrangement was signed on May 2000 in order to shield that country from the risk of contagion from Argentina and Brazil. Eventually, as the situation deteriorated, Uruguay was forced to use the resources committed by the Fund, and a new much larger program was approved on May 2002. Following two augmentations, that program became the largest in the history of the IMF if measured with respect to the size of the recipient economy.

This distinction between 'inherited' and 'new' programs is not trivial. Indeed, the presence of inherited programs implies that, prior to the eruption of the debt problem the IMF was already financially exposed to the countries which undertook the restructuring. Unless total fund's exposure increases, augmentations of existing programs or programs approved during the restructuring in order to succeed the inherited ones, do not provide fresh resources and, at least partially, do simply roll-over existing obligations to the Fund. This tends to undermine the debtor-in-possession argument as a justification for the policy of Lending Into Arrears. Furthermore, it may create a conflict of interest for the IMF, which may come to be perceived as primarily concerned with safeguarding its resources and preserving its preferred creditor status. In turn, this tends to undermine the Fund's legitimacy as an independent actor charged with providing a public good aimed at improving the outcome of the restructuring and limiting its impact on international prosperity. This conflict of interests tends to be accentuated in the case of large inherited programs where the Fund may fear the consequences of an extension of the default to multilateral obligations. This was the case of Argentina, which contributes to explain why the involvement of the Fund in that restructuring turned out to be so contentious.

In any case, there are a number of dimensions of the Fund's involvement in sovereign debt restructurings that go beyond the mere provision of financial assistance. A first relevant question is whether the IMF exerted any discernible influence on the sovereigns' decision to default or restructure. This is not easy to tell given that, for obvious reasons, the discussions between the Fund and its members on such sensitive issues are not made public. In addition, it is the IMF's firm policy not to interfere with members' contractual obligations. However, in some cases many observers believe the Fund to have played a significant role in the decision making process that resulted in the launching of the restructuring. This would be the case of Ecuador, Ukraine and Uruguay, in the first case to address a clearly unsustainable situation ${ }^{6}$, and in the latter cases to fill residual financing needs under the Fund supported programs. In Argentina and Russia, the Fund did also play a role in the decision to default, albeit an indirect one. Indeed, in both cases after having lost access to international financial markets, the suspension of the Fund's financial support dried up the last available significant source of foreign exchange to continue honouring sovereign debt. A third scenario arises when the Paris Club opens the restructuring process, as was the case for the Dominican Republic, Pakistan and Serbia. Under this scenario, the IMF is involved in the first place as a pre-requisite for obtaining the Paris Club treatment, and private

6. Stanley Fisher acknowledged in May 2000 having discussed with Ecuador the pros and cons of a default of, "pointing out the risks of disruptive legal challenges in case of a default and the difficulties of sustaining a viable cash position in case of staying current on debt obligations". 
creditors are involved later in fulfilment of the comparability of treatment clause. Although it is difficult to argue that the Fund influenced the decision to renegotiate debt, it is clear that it played a pivotal role in this well established restructuring framework.

A second crucial dimension of the Fund's involvement in debt workouts is the setting of the resource envelope of the restructuring. This relates to the macroeconomic framework and conditionality embedded in Fund supported programs approved to support a restructuring. The Fund's role as an adjustment agent is undisputed in 'traditional' IMF programs. During a restructuring, however, the level of domestic adjustment associated with the Fund's conditionality is unavoidably linked to the relief or haircut that is necessary from private creditors in order to restore debt sustainability. As a result, it is likely that the establishment by the Fund of an adjustment path influences the negotiation between the sovereign debtor and its private creditors.

In most of the case studies analyzed here, the IMF has continued to play the role of an adjustment agent through the programs approved in the context of a restructuring. This was particularly clear when the Paris Club was involved early on, again as part of the well institutionalized restructuring framework described above. Although the Paris Club was only involved at a later stage of the restructuring, or not involved at all, this also tended to be the case for Ecuador, Ukraine and Uruguay. Conversely, the Fund played at best a minor role in setting the resource envelope of the Argentine and Russian restructurings. In the latter case, the IMF programs were off-track when the novation scheme was carried out and when an agreement was reached with the London Club in August 2000. Instead, an on-track program was in place when official bilateral debt was restructured in August 1999. In Argentina, in turn, the program's conditionality was deliberately set in soft and short-term oriented terms: the September 2003 SBA established a floor on the primary surplus of 3\% of GDP while fiscal targets for 2005 and 2006 were not even specified. Furthermore, the program was suspended in August 2004. As a result, domestic adjustment was entirely left to be determined by the bargaining process between the government and its creditors. In this dimension of the Fund's involvement, the inherited character of the program was crucial given that, at least to some extent, the Fund was held hostage by the Argentine threat of defaulting on its multilateral obligations, while private creditors were far from viewing the institution as an independent or uninterested part in the restructuring process.

Intimately linked to the above is the Fund's role as a provider of information. This third potential dimension of the Fund's involvement is particularly relevant in the context of sovereign debt restructurings given the heightened uncertainty and informational asymmetries that tend to characterize such episodes. No consistent approach seems to have characterized the Fund's involvement in that respect. Indeed, there are substantial variations in the amount of information disclosed by the Fund in the various cases under consideration. This is probably due to the fact that member states have the right to preclude the Fund from disclosing certain market sensitive pieces of information. As a result, the informational role of the Fund tends to be more intense in 'market-friendly' restructurings. For instance, the Fund published most program-related documents in the cases of the Dominican Republic or Uruguay. Instead, few documents were published in the cases of Argentina and Ecuador. Although references to debt sustainability are relatively frequent in program-related documents, no fully-fledged debt sustainability analysis was provided by the IMF in most of the cases under consideration. 
A fourth dimension of the Fund's involvement in sovereign debt restructurings is the provision of incentives to the parts involved in the process. The Fund has various instruments to provide such incentives. A central one is the good faith clause. Indeed, by conditioning the Fund's financial support to the authorities' good faith, that clause is aimed at creating incentives to adopt a collaborative stance in the debt workout. However, in spite of the 2002 attempt to clarify its content, assessing compliance with the good faith criterion is fundamentally judgemental and sometimes arbitrary. This is especially illustrated by the Argentine case, where the Fund's program was not suspended on the basis of a breach of the good faith clause even if most observers believe that, rather than engaging in a constructive dialogue, the authorities simply presented a series of take or leave it offers clearly detrimental to creditors' interests. As a result, at least in its current form, the good faith clause has lost much of its credibility as an enforceable obligation attached to the Fund's lending into arrears.

Additionally, the Fund has often tried to coordinate creditors by encouraging participation in the debt exchange. This usually takes the form of a comfort letter issued by the IMF's managing director to the members of the financial community in support of the authorities' economic program and the terms of the restructuring. In some cases, the Fund has gone beyond the mere provision of its seal of approval. This was especially the case for Uruguay, where the Managing Director made it clear that an insufficient participation in the debt exchange could lead to a suspension of the Fund's financial support and, thereby, to a much higher likelihood of a sovereign default. Indeed, the Comfort letter issued on April 22, 2003 specified that "(...) achieving these objectives is a condition for completion of the next (third) review under Uruguay's stand-by arrangement. A successful debt exchange requires high participation to allow the program to go forward and the forthcoming review to be completed". 


\section{$5 \quad$ Conclusions and Policy Implications}

One of the main conclusions that can be extracted from our case studies is the lack of consistency that has tended to characterize the involvement of the IMF in recent sovereign debt restructurings. Indeed, we have discerned several country specific factors shaping the Fund's approach to most of the dimensions of the restructuring processes analyzed above ${ }^{7}$. A first question to be raised is whether the IMF should preserve this case by case approach, or whether it should adopt a more systematic framework to shape its involvement in countries that are renegotiating sovereign debt. The current case by case approach has had the advantage of providing the Fund with some degree of flexibility to adapt to a changing world and to customize its crisis resolution strategies to potentially very different types of debt crises. However, this lack of consistency tends to exacerbate the uncertainty and informational asymmetries that are often associated with sovereign debt restructurings, and provides fertile ground for criticism by creating the perception that creditors or debtors are treated unequally depending on the specific circumstances that surround each crisis. The international community, therefore, needs to decide whether the IMF should play a more standardized role in sovereign debt restructurings and, if so, in what dimensions and through which instruments.

An important obstacle to frame the Fund's role in debt restructurings is the lack of a policy or instrument designed specifically for that purpose. This paper has focused on the policy of lending into arrears given that, more often than not, the Fund's programs in place during a restructuring are implemented under that policy. However, there are significant exceptions in the context of purely pre-emptive restructurings such as Uruguay's, or when arrears arise only with official or domestic creditors, as was the case in Pakistan. In any case, even the LIA policy fails to specify the role that the IMF is to play during sovereign restructurings ${ }^{8}$. Indeed, rather than a policy in the broad sense of the term, it simply constitutes a device to legalize the Fund's lending in a very specific scenario, introducing loose procedural requirements which are absent in 'traditional' programs. A second question, therefore, is whether the current procedural approach ought to be maintained or whether, instead, the LIA policy should be endowed with a meaningful economic rationale. By that we mean specifying the role to be played by the IMF in a number of specific dimensions in such a way as to contribute to improve the outcome of sovereign debt restructurings.

As argued above, a first dimension is the role of the IMF in the decision making process that leads to the launching of the restructuring. The articles of agreement establish that a crucial element of the Fund's mandate is to provide members with "opportunities to correct maladjustments in their balance of payments without resorting to measures destructive of national or international prosperity". Accordingly, the IMF's firm policy is to avoid interfering with members' contractual obligations. However, when a country's debt position becomes unsustainable, the IMF may have a role to play in advising country authorities on the best course of action to minimize the cost of an unavoidable restructuring on domestic and international prosperity. In this respect, our case studies suggest that, as

7. Part of this lack of consistency is due to the fact that some of the case studies covered here date prior to the clarification of the LIA 'good faith criterion' in 2002, and the introduction of DSAs in 2002 and 2003. However, even after these dates, our case studies have identified a number of inconsistencies.

8. In addition, the Fund's LIA policy also applies to the case of minor arrears which may not require a broad-based debt restructuring. This paper has deliberately left this scenario out of its focus. 
debt problems mount, countries have a tendency to gamble for redemption by applying partial measures in order to bridge short-term liquidity pressures. Such measures are often detrimental in the medium to longer term, either by simply delaying the resolution of the crisis, by increasing the burden of long-term debt, or by pushing the domestic financial system to the brink of insolvency. The IMF, therefore, should avoid supporting measures such as the Argentine mega swap or the Russian pre-default debt swap. On occasions, this may entail advising countries to adopt a comprehensive approach to restore debt sustainability at an early stage of the crisis, which may even require advising to restructure.

The second potential dimension of the Fund's involvement is the provision of the 'resource envelope' of the restructuring through the macroeconomic framework and conditionality embedded in its programs. Some observers have argued that the Fund should restrain from fulfilling that function in order not to interfere with the negotiations between the sovereign and its creditors. The proponents of that view consider that asking the IMF to set the resource envelope of the debt workout constitutes an interventionist practice inconsistent with the market-based approach adopted by the international community to handle sovereign restructurings. Should deterministic macroeconomic frameworks be dropped from LIA programs, the Fund would be effectively abandoning its role as an adjustment agent in a very particular set of circumstances. Given that this role is undisputed in 'traditional' programs, the question is whether the presence of external arrears or an ongoing restructuring process justifies restricting the scope and functions of IMF-supported programs.

Our case studies suggest that sovereign debt restructurings tend to be smoother when the Fund retains its role as an adjustment agent. This is particularly clear in the restructurings which involved the Paris Club at an early stage, which may be the result of the specific features of a well institutionalized framework, a clear division of labour within the official sector, and the effectiveness of the comparability of treatment clause. In turn, the most disruptive and contentious restructurings analyzed here have been precisely those in which the IMF did not act as an adjustment agent, i.e. the Argentine and the Russian cases. There is some evidence to argue, therefore, that the provision of a macroeconomic framework to anchor expectations does effectively promote a constructive dialogue between the sovereign and its creditors. Indeed, this may be a crucial component of the public good provided by the Fund in a distressed debt situation particularly prone to market failures. In any case, this is one of the dimensions of the Fund's involvement in which consistency is most needed, given that a case by case approach equates to an unequal treatment of members in terms of the conditions demanded from them to access the Fund's financial support.

In addition, the definition of a macroeconomic adjustment path under an IMF-supported program is not necessarily detrimental of debtor/creditor negotiations. This is so because IMF programs define a resource envelope only in the short-term (one to three years). The debt relief resulting from the negotiations between creditors and debtors, instead, depends on a much longer adjustment path. Consequently, even if the IMF agrees with its members on an adjustment path over the time horizon of a program, there is still room for the negotiations with creditors to yield very different results in terms of debt relief.

The third potential dimension is the informational role of the IMF. As argued above, the amount of information disclosed by the Fund during sovereign debt restructurings has varied substantially from case to case. What is perhaps more surprising is that the format and scope of debt sustainability analyses included in published IMF documents has also exhibited substantial variations. In fact, the IMF has generally restrained from systematically disclosing 
full-fledged debt sustainability analyses (DSAs) of countries engaged in a debt restructuring. A possibility to systematize the informational role of the Fund during sovereign debt restructurings could be precisely that of requiring the institution to provide a DSA to the parts involved. In recognition of the specificities posed by a sovereign debt restructuring This may conflict with the Fund's transparency policy, under which publication of the DSA is voluntary and a prerogative of the member. However, the very specific scenario posed by sovereign debt restructuring processes could constitute an exception to that rule, and countries could be required to accept the divulgation of their DSA as one of the proofs of their 'good faith' when engaged in a LIA program.

A relevant question is whether such DSAs produced by the Fund would have a comparative advantage over DSAs produced by the private sector. In principle, the main source of this comparative advantage would stem from the independence that can be attributed to the Fund. In addition, especially in the absence of 'inherited' programs, the Fund should be expected to be better positioned than the private sector to access confidential information given its special relationship with its members. Finally, information has some of the features of a public good, implying that the private sector is likely to devote a sub-optimal volume of resources for its provision. This is especially the case in a world of securitized debt in which most individual bondholders are unlikely to have the resources and know-how to carry out a DSA.

The fourth potential dimension of the Fund's involvement is the provision of incentives to the parts engaged in the negotiations. The main instrument used by the Fund to fulfil that objective is the good faith criterion. This instrument, however, has exhibited important deficiencies, especially in the Argentine case. As a result, some observers have argued that it may be worth erasing that criterion from the LIA framework. This would require searching for alternative instruments to encourage constructive negotiations. A possibility, put forward recently by the Bank of England, could be the substitution of the good faith criterion by price incentives, i.e. introducing a surcharge on the cost of LIA programs. The argument goes that this would contribute to internalize the cost of delaying the restructuring process, thereby creating incentives for country authorities to engage early on in a constructive dialogue with private creditors. The problem, however, is that it may be difficult to legitimize this surcharge in a situation in which private creditors are being asked to absorb substantial losses in order to restore a country's debt sustainability. In addition, especially in the case of 'inherited' programs, adding such a surcharge in a distressed context may increase the risk of a default on multilateral obligations, thereby intensifying a potential challenge to the Fund's preferred creditor status.

Instead of eliminating the good faith criterion, another possibility could be to clarify that concept. This would require the introduction of objective and observable parameters to evaluate the sovereign's good faith. It has been argued that the Principles for Stable Capital Flows and Fair Debt Restructurings could be used for that purpose. An obstacle, however, is that although the Fund broadly supported the initiative, it has shown reluctance to incorporate the principles in its own internal operative. This is partly due to a far from monolithic support on the part of emerging issuers, and to the perception that the principles may be somewhat biased in favour of private creditors' interests. Moreover, there are some differences between current Fund's policies and some aspects of the Principles such as the use of the creditor committees (see Progress Report on Crisis Resolution, SM/05/107). In any case, the principles could be used as a basis for developing more substantive guidance for the assessment of the good faith criterion. In particular, the IMF could focus on securing some 
level of inter-creditor equity, trying to avoid unjustified discriminatory practices. This could be shaped along the lines of the Paris Club comparability of treatment clause, which has contributed to restrain discrimination and secure some level of equitable burden-sharing in past restructurings. As argued later, this framework would need to recognize the specificities of domestic creditors.

Our case study analysis has revealed that the presence of 'inherited' programs can impair the Fund's potential to play a substantive role in restructuring processes. Indeed, the Fund's ex ante financial exposure to the countries that launch a restructuring has the potential to create a conflict of interests with implications for the four dimensions mentioned above. This conflict of interests increases with the size of the 'inherited' program. In fact, a modest ex ante financial exposure may even facilitate the ex-post involvement of the IMF by providing some degree of continuity to the program relation with the country concerned. However, as suggested by the Argentine case, if exceptionally large, inherited programs can invalidate the debtor-in-possession argument to justify the provision of official finance in the context of LIA programs, and jeopardize the Fund's legitimacy vis-à-vis private creditors as an adjustment agent and provider of information and incentives. Given that it is very likely that 'inherited' programs will continue to be a fact of life in future debt restructurings, this issue should be taken on board in the upcoming review of the LIA policy.

A possibility to mitigate this conflict of interests would be to automatically suspend 'inherited' programs at the time of a sovereign default. The member would lose access to undisbursed resources, and would not be expected to make repurchases until the resumption of private debt servicing. After the default and suspension of the inherited program, the Fund could approve a new 'interim' program providing new resources under the LIA policy. Although the legal implications of such a framework would need to be discussed in great detail, it could have the following advantages. First of all, rather than simply rolling-over 'inherited' obligations, LIA programs would be effectively providing 'fresh' resources to cope with the crisis and mitigate the economic dislocation caused by the restructuring. This would reinforce the debtor-in-possession justification for the Fund's financial assistance to countries in default. Second, the Fund's leverage would be likely to be reinforced under this framework. Indeed, the prospect of acceding additional IMF resources rather than simply rolling over existing obligations could realign countries' incentives, making compliance with the programs' conditionality (including the good faith criterion) likelier. In addition, this framework would reduce countries' scope to threaten with defaulting on their multilateral obligations in order to press for the approval of successive program reviews during a sovereign debt restructuring.

We consider that the introduction of a standstill on purchases and repurchases of 'inherited' programs following a sovereign default would not substantially alter the seniority status of IMF loans because such obligations would never be made subject to a re-negotiation process (as opposed to other official obligations such as Paris Club bilateral loans). The IMF may want to underline this point by introducing some sort of penalty charge proportional to the suspended repurchases (and maybe also to the duration of the program suspension) payable after the resumption of private debt servicing. In fact, by reinforcing the aforementioned debtor in possession rationale for LIA programs, such a scheme could even reinforce the legitimacy of the Fund's preferred creditor status. It would also address one of the criticisms of the policy of lending into arrears in its current form: that rather than being targeted at mitigating the economic dislocation caused by the crisis, financial assistance following a sovereign default is mainly targeted at avoiding missed payments on IMF loans and, thereby, at defending the Fund's own financial position. 
We are aware that this reform, by committing the institution to provide fresh funding and given its interest in safeguarding its own resources, could have important ex-ante effects. It could reduce IMF's incentives to lend before financial problems appear, as to guarantee space for providing capital when problems arise. Observed have argued, however, that the IMF tends to over lend previous to financial stress episodes at the cost of being forced to restrain from further lending when debt problems blow up. If this is actually the case, then the design we propose could, indeed, partly correct this situation.

Another problem associated with the current framework is that the LIA policy basically ignores arrears to private domestic creditors. A first related problem is that, as mentioned above, in the current context of financial globalization, the dividing line between domestic and external debt is becoming increasingly blurred ${ }^{9}$. In addition, as a result of this bias in the LIA policy, the IMF may have devoted insufficient attention to the treatment of domestic creditors in sovereign debt restructurings. Our analysis suggests that an extensive involvement of domestic creditors could signal a "gambling for resurrection" strategy and may anticipate external solvency problems. As a result, focusing solely on external debt could delay the Fund's intervention and exacerbate the cost of the crisis, especially if the early involvement of domestic creditors jeopardizes the future solvency of the domestic financial sector. Conversely, once the country has already defaulted, focusing the LIA policy on the restructuring of external debt may not be consistent with the objective of securing some degree of inter-creditor equity. Summing up, in its current form, the LIA policy does not take sufficiently into account sovereigns' shifting incentives regarding the involvement of domestic vs. external creditors during a crisis. This may hamper the Fund's potential to mitigate the impact of sovereign debt restructurings.

A final question identified here is whether the scope of the LIA policy should be broadened to encompass the role of the IMF in all restructurings, and not only in those in which the sovereign has fallen into arrears with its private creditors. Various arguments could support such a broadening of the LIA policy. First of all, pre-emptive restructurings were often conducted under the threat of default should the debt exchange fail, which tended to blur the distinction with the post-default scenario ${ }^{10}$. Furthermore, our analysis has identified a number of potential dimensions of the Fund's involvement in debt restructurings which could have applied both to our pre-emptive and to post-default cases. Indeed, the Fund's advice on the best course of action to restore debt sustainability as well as its role as an adjustment agent and provider of information and incentives were equally relevant in both scenarios. In this context, it is arguable whether the presence of external arrears to private creditors has more of an economic justification as a trigger of a specific IMF policy than a pre-emptive broadbased revision of the sovereign's debt terms.

9. A recent episode in Uruguay has illustrated the ambiguity associated with basing the LIA policy in this distinction between domestic and foreign creditors. In June 2004, a resident bank sold a US\$2.3 million claim on the government to a non-resident. Because this equated to the emergence of arrears with external creditors, in June 2006 a case was made by the new owner of the claim that the LIA policy ought to have been activated, and that the IMF should press the Uruguayan authorities to negotiate in good faith to clear that arrear.

10. A case in point was that of Uruguay, where the IMF made the completion of the third review of the program conditional to a high participation in the exchange. It was quite clear at that point that a suspension of the Fund's financial support would have almost unavoidably resulted in a default. 


\section{REFERENCES}

CHIODO, A. J., and M. T. OWYANG (2002). A case study of a currency crisis: The Russian default of 1998, Federal Reserve Bank of St. Louis.

DE BOLLE, M., B. ROTHER and I. HAKOBYAN (2006). The level and composition of Public Sector Debt in Emerging Market Crises, IMF Working Paper 06/186.

DÍAZ-CASSOU, J., A. ERCE-DOMínGUEZ and J. VAZQUEZ-ZAMORA (2008). Recent Episodes of Sovereign Debt Restructurings. A Case-Study Approach, Banco de España Occasional Paper No. 0804.

EICHENGREEN, B., and R. PORTES (1989). Dealing with debt: The 1930s and the 1980s, Working Paper No. 259, World Bank.

ENDERLEIN, H., L. MULLER and C. TREBESH (2007). Debt Disputes: Measuring Government Coerciveness in Sovereign Debt Crises, mimeo.

EUROPEAN CENTRAL BANK (2005). The role of the IMF in sovereign debt restructurings.

FERNÁNDEZ, A., P. GARDA and N. PERELMUTER (2003). Calificaciones, crisis de deuda y crisis bancaria: la experiencia uruguaya en el 2002, Centro de Investigaciones Económicas.

FINGER, H., and M. MECAGNI (2007). Sovereign Debt Restructuring and Debt Sustainability: An analysis of Recent Cross-Country Experience, Occasional Paper No. 255, International Monetary Fund.

GOBBIN, N., and B. MERLEVEDE (2000). "The Russian Crisis: A Debt Perspective", Post-Communist Economies, Vol. 12, No. 2.

GOLOV, R., and R. MATTHEWS (1999). The Russian Crisis: Causes, Consequences and Implications for the Future, Occasional Paper 35, Kingston University.

IMF (1999). IMF Policy on Lending into Arrears to Private Creditors.

- (2003). Crisis Resolution in the Context of Sovereign Debt Restructurings: A summary of considerations.

- (2004). Progress Report to the International Monetary and Financial Committee on Crisis Resolution.

- (2005). Aspects of the Fund's Lending Into Arrears Policy.

— (1995-2006). Staff Report for the Article IV Consultation (various countries).

KRUEGER, A. (2001). A New Approach to Sovereign Debt Restructuring, Speech at the National Economists' Club Annual Members' Dinner, American Enterprise Institute.

OWEN D., and D. ROBINSON (Eds.) (2003). Russia Rebounds, International Monetary Fund, Washington D.C.

REINHART, C., K. ROGOFF and M. SAVASTANO (2003). Debt intolerance, NBER.

STURZENEGGER, F., and J. ZETTELMEYER (2007). "Creditors losses versus debt relief: Results from a decade of sovereign debt crises", Journal of the European Economic Association, 5 (2-3).

— (2006). Haircuts: Estimating Investor losses in Sovereign Debt restructurings, 1998-2005, IMF Working Paper 05/137.

UKRAINE WEEKLY (1998). Ukraine's economy: staving off collapse, December. 


\section{Appendix 1: chronology of events}

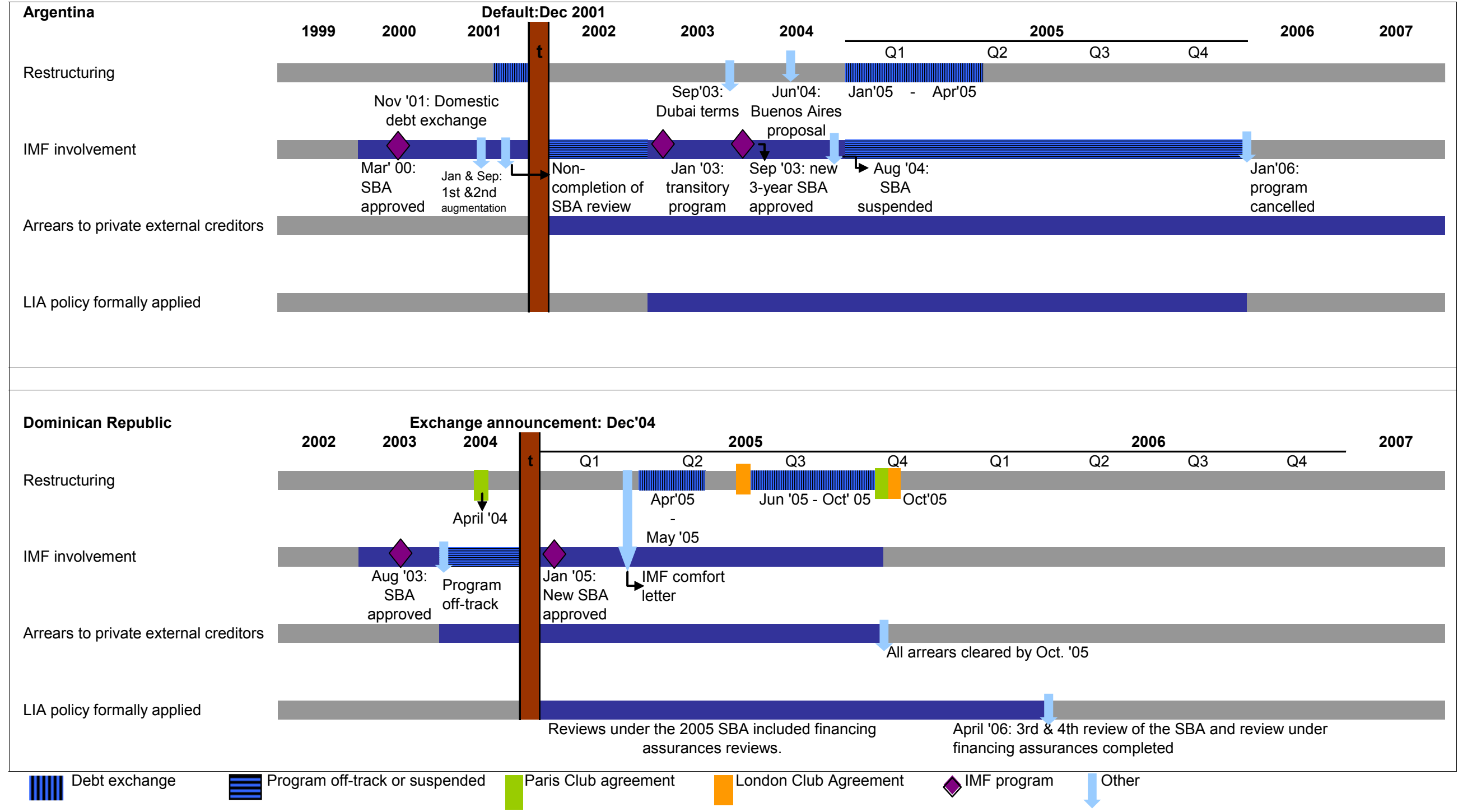




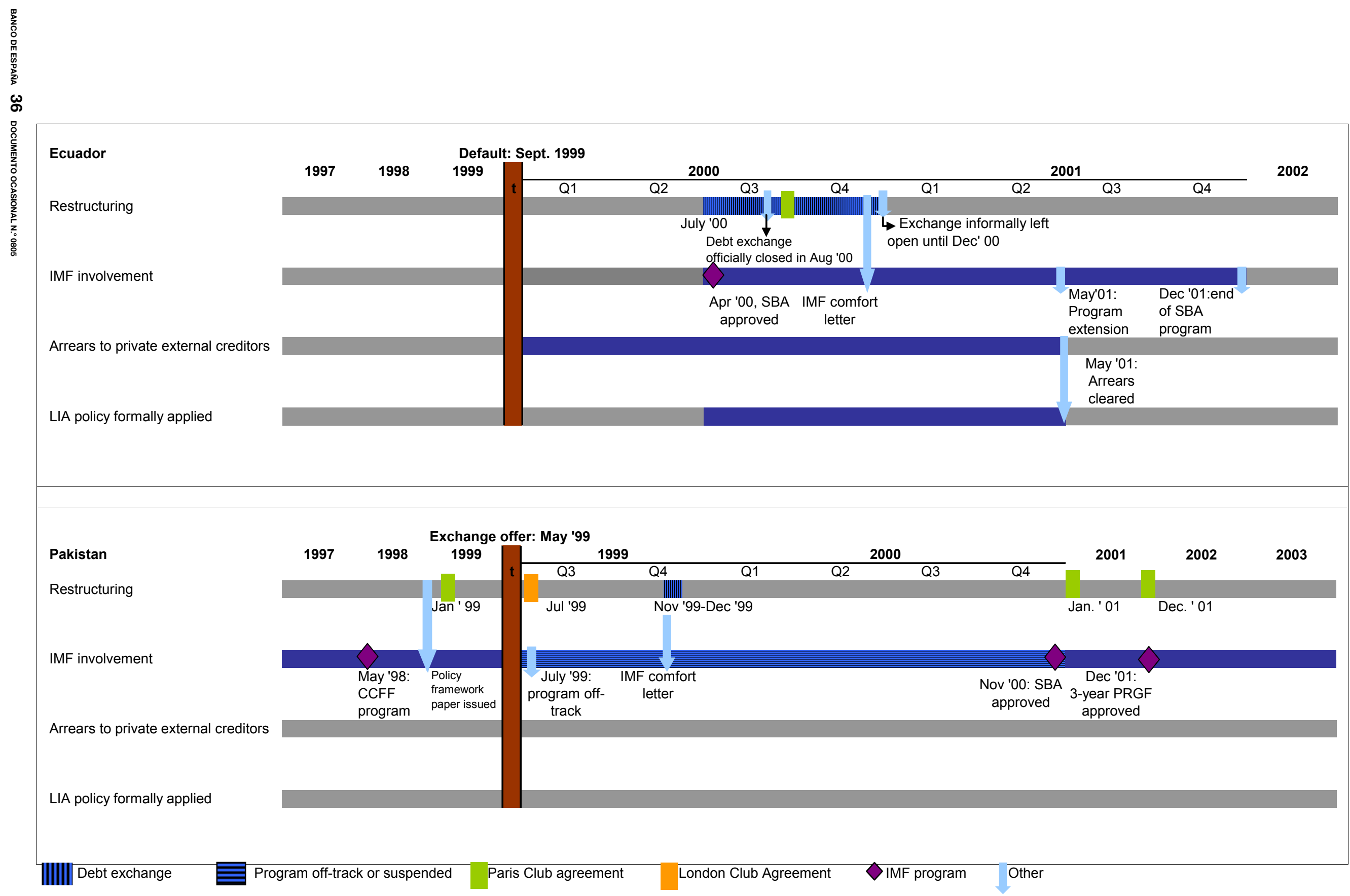









\section{Ukraine}

Restructuring

IMF involvement

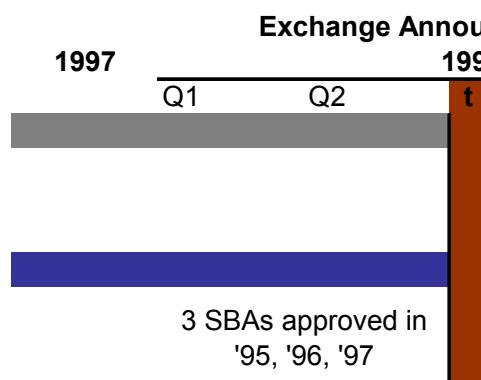

ucement:Aug'98

Arrears to private external creditors

'95, '96, '97

\begin{tabular}{l|c|}
\hline \multicolumn{1}{|c}{ Q3 } \\
Aug '98 \\
\hline $\begin{array}{l}\text { Sep '98: } \\
\text { EFF } \\
\text { approved }\end{array}$
\end{tabular}
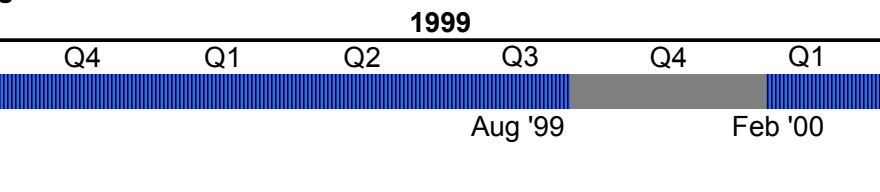

April'00

2000 Q3 Q4 approved

May '99: program Aug '99: Program went

\section{augmented off -track after the 3rd}

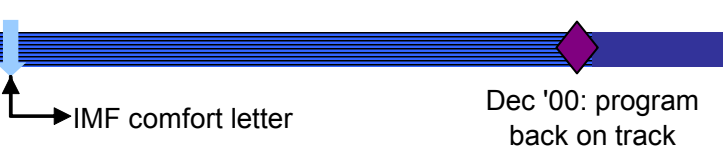

LIA policy formally applied

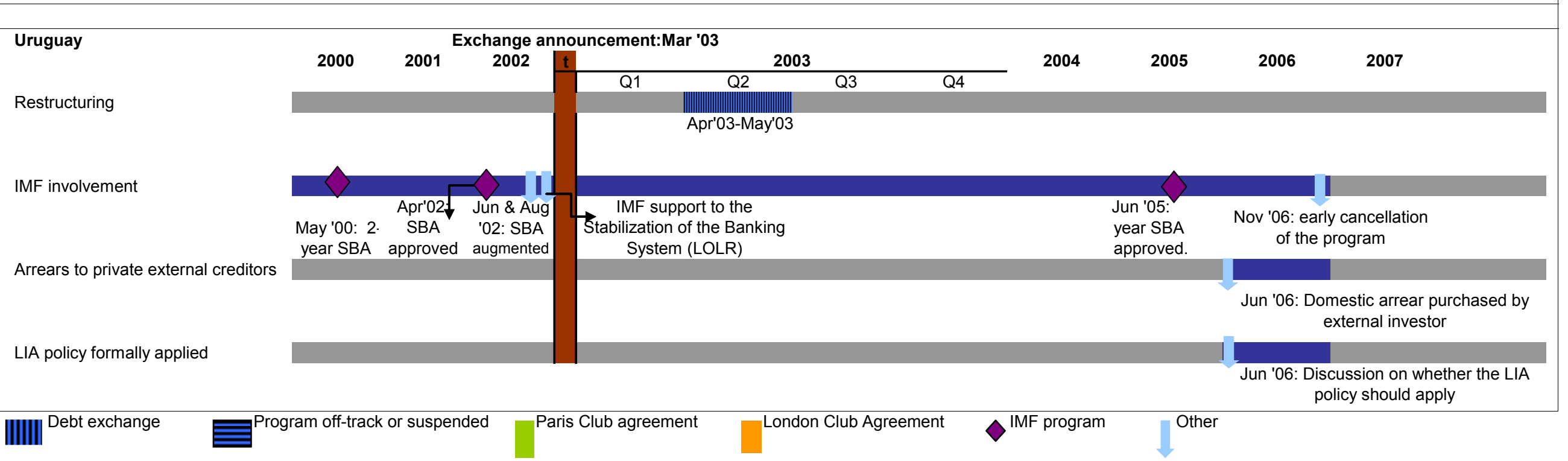


Appendix 2: Key features of IMF-supported programs.

\begin{tabular}{|c|c|c|c|c|c|c|}
\hline & & Program type & Approval & Duration & Amount ( $\%$ of quota) & Comments \\
\hline \multirow{5}{*}{ Argentina } & \multirow{3}{*}{$\begin{array}{l}\text { Inherited } \\
\text { programs }\end{array}$} & SBA & Mar 00 & 3 years & SDR 5.4 bn (255\%) & Focus on fiscal conditionality. Program failed. \\
\hline & & $\begin{array}{c}1 \text { st } \\
\text { augmentation }\end{array}$ & Jan 01 & - & SDR 5.2 bn (246\%) & $\begin{array}{c}\text { Relaxation of fiscal targets;reviews approved } \\
\text { despite breaches in fiscal targets;support to } \\
\text { the mega swap } \\
\end{array}$ \\
\hline & & $\begin{array}{c}2 \text { nd } \\
\text { augmentation }\end{array}$ & Sep 01 & - & SDR 6.3 bn (300\%) & $\begin{array}{l}\text { Non-completion of the fifth } \\
\text { review; disbursements suspended after default }\end{array}$ \\
\hline & \multirow{2}{*}{$\begin{array}{l}\text { Ex post } \\
\text { involvement }\end{array}$} & $\begin{array}{l}\text { Transitory } \\
\text { program }\end{array}$ & Jan 03 & 7 months & $\begin{array}{c}\text { SDR } 2174.5 \mathrm{mn} \\
(103 \%)\end{array}$ & Soft conditionality \\
\hline & & SBA & Sep 03 & 3 years & SDR 8.9 bn (424\%) & $\begin{array}{l}\text { Soft conditionality; short-term orientation of } \\
\text { fiscal targets; suspended in August } 2004\end{array}$ \\
\hline \multirow{2}{*}{$\begin{array}{l}\text { Dom. } \\
\text { Republic }\end{array}$} & \multirow{2}{*}{$\begin{array}{l}\text { Expost } \\
\text { involvement }\end{array}$} & SBA & Aug 03 & 2 year & $\begin{array}{l}\text { SDR } 437.8 \mathrm{mn} \\
(200 \%)\end{array}$ & Program failure; only first review completed \\
\hline & & SBA & feb-05 & 28 months & $\begin{array}{l}\text { SDR } 437.8 \mathrm{mn} \\
\quad(200 \%)\end{array}$ & Successful implementation \\
\hline Ecuador & $\begin{array}{l}\text { Ex post } \\
\text { involvement }\end{array}$ & SBA & April 00 & 1 year & SDR $226.7 \mathrm{mn}(75 \%)$ & Successful implementation \\
\hline \multirow{3}{*}{ Pakistan } & $\begin{array}{l}\text { Inherited } \\
\text { programs }\end{array}$ & EFF-ESAF & Oct 97 & 3 year & SDR $1136 \mathrm{mn}(110 \%)$ & Program failed. Off-track in July 99. \\
\hline & \multirow{2}{*}{$\begin{array}{c}\text { Expost } \\
\text { involvement }\end{array}$} & SBA & April 00 & 1 year & $\begin{array}{l}\text { SDR } 465 \mathrm{mn}(45 \% \text { of } \\
\text { quota) }\end{array}$ & Successful implementation \\
\hline & & PRGF & Dec 01 & 3 years & SDR $1033 \mathrm{mn}(100 \%)$ & Successful implementation \\
\hline \multirow{3}{*}{ Russia } & \multirow{2}{*}{$\begin{array}{l}\text { Inherited } \\
\text { programs }\end{array}$} & EFF & March 96 & 3 years & SDR 6.9 bn (160\%) & $\begin{array}{l}\text { Weak implementation; targets relaxed in } \\
\text { successive reviews }\end{array}$ \\
\hline & & Augmentation & Jul 98 & - & SDR 8.5 bll (143\%) & $\begin{array}{c}\text { Support to GKO swap. Program suspended } \\
\text { after the parliament failed to approve a fiscal } \\
\text { adjustment package. }\end{array}$ \\
\hline & $\begin{array}{l}\text { Ex post } \\
\text { involvement }\end{array}$ & SBA & Jul 99 & 17 months & SDR 3.3 bll (56\%) & $\begin{array}{c}\text { Only one purchase completed; program went } \\
\text { off-track as a result of delays in structural } \\
\text { reforms }\end{array}$ \\
\hline \multirow{2}{*}{ Serbia } & \multirow{2}{*}{$\begin{array}{l}\text { Ex post } \\
\text { involvement }\end{array}$} & SBA & Jun 01 & 10 months & SDR $200 \mathrm{mn}(43 \%)$ & $\begin{array}{l}\text { Stepping stone for the Paris Club treatment. } \\
\text { Successful implementation. }\end{array}$ \\
\hline & & EFF & May 02 & 3 years & SDR 650mn (139\%) & Delays in the completion of the last reviews. \\
\hline \multirow{4}{*}{ Ukraine } & \multirow{2}{*}{$\begin{array}{l}\text { Inherited } \\
\text { programs }\end{array}$} & SBA & Apr 96 & 9 months & US\$ 0.97 bll (71\%) & Successful implementation \\
\hline & & SBA & Aug 97 & 12 months & US\$ 0.53 bll (37\%) & $\begin{array}{c}\text { Only partial disbursement as a result of } \\
\text { breaches in macroeconomic conditionality. }\end{array}$ \\
\hline & \multirow{2}{*}{$\begin{array}{l}\text { Expost } \\
\text { involvement }\end{array}$} & EFF & Sep 98 & 3 years & US\$ 2.2 bll (165\%) & \multirow{2}{*}{\begin{tabular}{|} 
Explicit support to the restructuring. Difficult \\
implementation: program went off-track \\
various times and was only partially disbursed.
\end{tabular}} \\
\hline & & Augmentation & May 99 & - & US\$ 366 mll (20\%) & \\
\hline \multirow{5}{*}{ Uruguay } & \multirow{2}{*}{$\begin{array}{l}\text { Inherited } \\
\text { programs }\end{array}$} & SBA & May 00 & 22 months & SDR 150mn (49\%) & $\begin{array}{l}\text { Originally precautionary. Resources eventually } \\
\text { disbursed due to contagion from Argentina. }\end{array}$ \\
\hline & & SBA & Apr 02 & 2 years & SDR 594mn (194\%) & Tighter conditionality. Succesful progress \\
\hline & \multirow{3}{*}{$\begin{array}{l}\text { Ex post } \\
\text { involvement }\end{array}$} & $\begin{array}{c}1 \text { st } \\
\text { augmentation }\end{array}$ & Jun 02 & - & SDR 1.16 bn (378\%) & Focus on the banking crisis. \\
\hline & & $\begin{array}{c}\text { 2nd } \\
\text { augmentation }\end{array}$ & Aug 02 & - & SDR $376 \mathrm{mn}(123 \%)$ & $\begin{array}{c}3 \mathrm{~d} \text { review of the program made dependent on } \\
\text { participation in the debt exchange. }\end{array}$ \\
\hline & & SBA & Jun 05 & 3 years & $\begin{array}{c}\text { SDR } 766,25 \mathrm{mn} \\
(250 \%)\end{array}$ & Satisfactory implementation. \\
\hline
\end{tabular}


BANCO DE ESPAÑA PUBLICATIONS

\section{OCCASIONAL PAPERS}

0501 JOSÉ RAMÓN MARTÍNEZ-RESANO: Size and heterogeneity matter. A microstructure-based analysis of regulation of secondary markets for government bonds.

0502 ALICIA GARCÍA-HERRERO, SERGIO GAVILÁ AND DANIEL SANTABÁRBARA: China's banking reform: an assessment of its evolution and possible impact.

0503 ANA BUISÁN, DAVID LEARMONTH AND MARÍA SEBASTIÁ BARRIEL: An industry approach to understanding export performance: stylised facts and empirical estimation.

0504 ANA BUISÁN AND FERNANDO RESTOY: Cross-country macroeconometric heterogeneity in EMU.

0505 JOSÉ LUIS MALO DE MOLINA: Una larga fase de expansión de la economía española.

0506 VÍCTOR GARCÍA-VAQUERO AND JORGE MARTÍNEZ: Fiscalidad de la vivienda en España.

0507 JAIME CARUANA: Monetary policy, financial stability and asset prices.

0601 JUAN F. JIMENO, JUAN A. ROJAS AND SERGIO PUENTE: Modelling the impact of aging on Social Security expenditures.

0602 PABLO MARTÍN-ACEÑA: La Banque de France, la BRI et la création du Service des Études de la Banque d'Espagne au début des années 1930. (There is a Spanish version of this edition with the same number.)

0603 CRISTINA BARCELÓ: Imputation of the 2002 wave of the Spanish Survey of Household Finances (EFF).

0604 RAFAEL GÓMEZ AND PABLO HERNÁNDEZ DE COS: The importance of being mature: The effect of demographic maturation on global per-capita income.

0605 JUAN RUIZ AND JOSEP VILARRUBIA: International recycling of petrodolars. (The original Spanish version has the same number.)

0606 ALICIA GARCÍA-HERRERO AND SERGIO GAVILÁ: Posible impacto de Basilea Il en los países emergentes.

0607 ESTHER GORDO, JAVIER JAREÑO AND ALBERTO URTASUN: Radiografía del sector de servicios en España.

0608 JUAN AYUSO, ROBERTO BLANCO AND FERNANDO RESTOY: House prices and real interest rates in Spain.

0701 JOSÉ LUIS MALO DE MOLINA: Los principales rasgos y experiencias de la integración de la economía española en la UEM.

0702 ISABEL ARGIMÓN, FRANCISCO DE CASTRO AND ÁNGEL LUIS GÓMEZ: Una simulación de los efectos de la reforma del IRPF sobre la carga impositiva

0703 YENER ALTUNBAŞ, ALPER KARA AND ADRIAN VAN RIXTEL: Corporate governance and corporate ownership: The investment behaviour of Japanese institutional investors.

0704 ARTURO MACÍAS AND ÁLVARO NASH: Efectos de valoración en la posición de inversión internacional de España.

0705 JUAN ÁNGEL GARCÍA AND ADRIAN VAN RIXTEL: Inflation-linked bonds from a central bank perspective.

0706 JAVIER JAREÑO: Las encuestas de opinión en el análisis coyuntural de la economía española.

0801 MARÍA J. NIETO AND GARRY J. SCHINASI: EU framework for safeguarding financial stability: Towards an analytical benchmark for assessing its effectiveness.

0802 SILVIA IRANZO: Delving into country risk. (There is a Spanish version of this edition with the same number.)

0803 OLYMPIA BOVER: The Spanish survey of household finances (EFF): Description and methods of the 2005 wave.

0804 JAVIER DÍAZ-CASSOU, AITOR ERCE-DOMÍNGUEZ AND JUAN J. VÁZQUEZ-ZAMORA: Recent episodes of sovereign debt restructurings. A case-study approach.

0805 JAVIER DÍAZ-CASSOU, AITOR ERCE-DOMÍNGUEZ AND JUAN J. VÁZQUEZ-ZAMORA: The role of the IMF in recent sovereign debt restructurings: Implications for the policy of lending into arrears.

\section{BANCODEESPAÑA}

Eurosistema
Unidad de Publicaciones Alcalá, 522; 28027 Madrid

Telephone +3491338 6363. Fax +34913386488

e-mail: publicaciones@bde.es www.bde.es 